
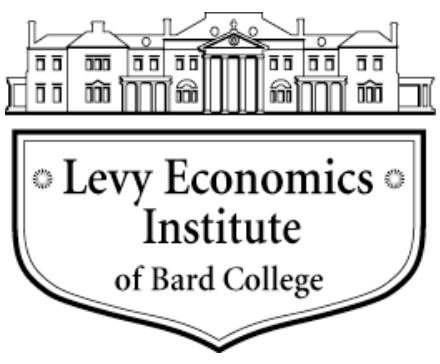

Working Paper No. 802

\title{
Shadow Banking: Policy Challenges for Central Banks
}

by

\author{
Thorvald Grung Moe* \\ Levy Economics Institute of Bard College
}

May 2014

* Thorvald Grung Moe is a senior adviser at Norges Bank. The views expressed in this paper are those of the author and do not necessarily represent the position of the Bank.

The Levy Economics Institute Working Paper Collection presents research in progress by Levy Institute scholars and conference participants. The purpose of the series is to disseminate ideas to and elicit comments from academics and professionals.

Levy Economics Institute of Bard College, founded in 1986, is a nonprofit, nonpartisan, independently funded research organization devoted to public service. Through scholarship and economic research it generates viable, effective public policy responses to important economic problems that profoundly affect the quality of life in the United States and abroad.

Levy Economics Institute

P.O. Box 5000

Annandale-on-Hudson, NY 12504-5000

http://www.levyinstitute.org

Copyright (C) Levy Economics Institute 2014 All rights reserved

ISSN 1547-366X 


\begin{abstract}
Central banks responded with exceptional liquidity support during the financial crisis to prevent a systemic meltdown. They broadened their tool kit and extended liquidity support to nonbanks and key financial markets. Many want central banks to embrace this expanded role as "market maker of last resort" going forward. This would provide a liquidity backstop for systemically important markets and the shadow banking system that is deeply integrated with these markets. But how much liquidity support can central banks provide to the shadow banking system without risking their balance sheets? I discuss the expanding role of the shadow banking sector and the key drivers behind its growing importance. There are close parallels between the growth of shadow banking before the recent financial crisis and earlier financial crises, with rapid growth in near monies as a common feature. This ebb and flow of shadow-banking-type liabilities are indeed an ingrained part of our advanced financial system. We need to reflect and consider whether official sector liquidity should be mobilized to stem a future breakdown in private shadow banking markets. Central banks should be especially concerned about providing liquidity support to financial markets without any form of structural reform. It would indeed be ironic if central banks were to declare victory in the fight against too-big-to-fail institutions, just to end up bankrolling too-big-to-fail financial markets.
\end{abstract}

Keywords: Financial Regulation; Financial Stability; Monetary Policy; Central Bank Policy JEL Classifications: E44, E52, E58, G28 


\section{Introduction}

The depth and length of the current financial crisis have been exceptional. The global financial system was close to a meltdown after Lehman Brothers filed for bankruptcy in September 2008. Central banks responded with unprecedented force and were able to restore stability to financial markets. As the recession dragged on, they broadened their tool kit and extended their liquidity support from single institutions to key markets. Many central banks also provided additional liquidity support through asset purchases, large-scale market interventions and other creative ways of easing credit conditions. As a result, central banks' balance sheets have grown dramatically compared to GDP.

Scholars broadly agree that these untraditional polices saved the global financial system from a systemic meltdown in 2008. There is less agreement about the way forward and how central banks should conduct their liquidity policies in the future. Some want central banks to expand their discount window lending and become "market makers of last resort" (MMLR) (Carney 2008, 2011, 2013). Others are wary of such extensions of the government safety net and would prefer to rein in the expansion of the shadow financial system with stricter regulation (Tarullo 2013; Turner 2013, Wolf 2013).

The shadow banking system represents a special policy challenge for central banks, since its growth is closely linked to the introduction of stricter rules for the regulated banking system. The two parts of the financial system are also closely linked through a network of securities lending, rehypothecation, and repo- and derivatives markets. Recent proposals by international regulatory bodies to increase transparency and restrict the uncontrolled leverage of this highly pro-cyclical system should help, but will probably not be enough. Unless the expansion of the shadow banking system is curbed, central banks could risk becoming implicit guarantors of shadow banking liabilities.

My intuition is that there must be some limit to how far central banks should go in supporting the broader financial market in a crisis, especially when much of the on-going expansion is based on a "liquidity illusion" that markets are deep and safe and will be supported by central banks - almost for free. This has led to under-pricing of the true risk embedded in shadow banking instruments, and made them an artificially cheap source of funding. Even if central banks can create abundant amounts of official liquidity, there should be limits to their support of the private financial sector. But recent relaxations in the proposed liquidity regulations and suggestions that central bank facilities should be included in banks' liquidity 
reserves reflect the pressure on central banks to support core financial markets in a new crisis. Such an accommodative policy stance could, however, contribute to further financial fragility and ultimately lead to another government bailout — if asset prices collapse, central banks intervene and fiscal transfers are subsequently required to recapitalize central banks. This would be ironic, after the recent focus on ending taxpayer bailout of too-big-to-fail institutions.

\section{Shadow Banking Redefined}

There is a growing awareness that the shadow banking system is not a financial system distinctly different from regulated banking. Banks are big players in the shadow banking system, both as collateral providers and as repo participants. Money market funds are major funding sources for the big banks, and the OTC derivatives market is an integral part of the shadow banking system through its extensive reliance on pledged collateral. Gabor (2013) shows that big banks are dominant in the shadow banking system in Europe, and a recent Bank for International Settlements report notes that a few global banks dominate the global OTC market (BIS 2013c). By recasting the shadow banking debate in this light, we can appreciate that many of the on-going regulatory debates on collateral policies, minimum haircuts, liquidity rules, high-quality liquid assets, risk weights for sovereign debt, and the central banks' role as liquidity back-stoppers (be it LLR [Lender of Last Resort] or MMLR) are indeed tightly connected.

When G20 leaders in 2009 asked the Financial Stability Board (FSB) "to identify the main risks related to shadow banking and eliminate all dark corners in the financial sector," the initial approach focused on institutions outside the regulated banking system that could represent a threat to financial stability. According to this approach, the size of the global shadow banking system was estimated to be almost 70 trillion dollars, or $25 \%$ of global financial intermediation (Adrian, Ashcraft and Cetorelli, 2013). ${ }^{3}$

The FSB responded by establishing five separate work streams to deal with the challenges of shadow banking and the EU Commission launched its own consultation on how best to tackle systemic risk stemming from shadow banking entities and activities (FSB 2011; EU 2012). Through this work a more nuanced view of shadow banking has developed, focusing in particular on fragile repo funding, securities lending, derivatives trading, global liquidity

3 Based on total assets of "Other Financial Intermediaries" of the national accounts data, but not including insurance and pension funds 
creation and money market financing (EU 2013, Gabor 2013). As former FSA chairman Adair Turner observed (Turner 2012): "We need to understand shadow banking not as something parallel or separate from the core banking system, but deeply intertwined with it."

Key to this "new" understanding of the shadow-banking complex is the collateral intermediation function that underpins the financial plumbing of our market based financial system (Singh 2013b). The pro-cyclical nature of this collateral based financial system, through funding and asset price fluctuations, is now seen by many as the essential feature of the shadow banking system. Our understanding of the interaction between the regulated banking system, other regulated financial entities and privately organized markets is still incomplete, partly due to lack of data, but recent papers study the role of shadow banking liabilities in the money supply (Sunderam 2012) and explore the impact of shadow money creation on macroeconomic fluctuations (Moreira and Savov 2012).

This "new view" of shadow banking is reflected in the recent recommendations by the Financial Stability Board (FSB) (2013a) and the European Commission (2013), where the focus is now squarely on financial activities, like money markets, securitization, securities lending and repo markets, rather than on institutions. The EU Communication on Shadow Banking therefore recommends measures that will increase the transparency of shadow banking activities, as well as specific measures addressing the risk in money market funds and investment funds. The EU Commission also wants to reduce the risk associated with securities financing transactions; including measures to limit the extent of rehypothecation. "This mechanism can contribute to increased leverage and strengthen the pro-cyclical nature of the financial system, which then becomes vulnerable to bank runs and sudden deleveraging (EU 2013, p. 11).”

The recent FSB Global Shadow Banking Monitoring Report 2013 (FSB 2013b) notes that "further improvements in data availability and granularity will be essential for authorities to be able to adequately capture the magnitude and risks in the shadow banking system." Such data will be essential to judge risks and the potential systemic impact of the shadow banking system. They add: "In the future, improvements in data availability should allow for the mostly entitybased focus of the 'macro-mapping' to be complemented with an activity-based monitoring to cover developments in relevant markets where shadow banking activity may occur, such as repo markets, securities lending and securitization (ibid.).”

\footnotetext{
${ }^{4}$ See Deryugina (2009) for an instructive discussion of rehypothecation issues
} 
The growth in shadow banking activities has coincided with a sharp decline in the role of direct bank credit intermediation. While almost three quarters of all credit were funded by shortterm bank liabilities back in the mid-1940s in the US (bank and non-bank credit), that number fell to fifteen percent just before the financial crisis (Adrian, Ashcraft and Cetorelli 2013). But Adrian et al. also show how banks have retained important functions related to shadow finance, such as issuers of securities, underwriters in charge of placement, and servicers that take care of the revenue streams from securitization. As a result, very little securitization activity is conducted without participation of regulated banking entities (Cetorelli and Peristiani 2012).

Adrian et al (2013) note also that the takeaway form this recent research is that "at closer inspection, regulated bank entities have kept a considerable footprint in modern financial intermediation." So, while the term "shadow banking" implies activity outside the purview of regulatory oversight, "regulated institutions are in fact heavily involved in these activities, both in funding their own operations and in extending credit and liquidity support to shadow banks beyond the regulatory perimeter" (Tarullo 2013).

This capacity of the shadow banking system to operate on a large scale in a way that creates bank-like liabilities through a complex chain on collateral transactions, have created multiple forms of feedbacks into the regulated banking system. The use and re-use of collateral exacerbates pro-cyclical dynamics and makes the whole financial system more fragile. When times are good, market participants tend to be more willing to let counterparties re-use collateral, increase market liquidity and thereby lower the cost of capital. But in more stressed market conditions, market participants become more sensitive to counterparty risk and more reluctant to re-use their collateral. This puts additional strains on already tight liquidity conditions and tends to amplify the pro-cyclicality of the shadow banking system. 


\section{Shadow Banking in the Past}

That private money is not cash and that all IOUs are not equal should not come as a surprise. The collapse of the shadow banking system during the recent global financial crisis is not unprecedented if we look closer at earlier crises. Henry Thornton made the same observations in his 1802 book - An enquiry into the nature and effects of the paper credit of Great Britain (1802, Chapter III, p. 37):

When confidence rises to a certain height in a country, it occurs to some persons, that profit may be obtained by issuing notes, which purport to be exchangeable for money; and which, through the known facility of thus exchanging them, may circulate in its stead.

Hyman Minsky (1982) noted that this desire for more cash than is available from its usual source sows the seeds for the next financial crises. During a boom, the margin of safety decreases and economic units take on more and more leverage. Money markets have a tendency to expand during boom periods, providing an elastic source of private credit. As money markets expand, a general decline in the liquidity of households and firms follows. This makes them vulnerable to a fall in asset values. There will be a general expectation about liquidity in key asset markets that cannot be sustained unless the central bank moves in and supports the price, i.e., monetization by the central bank. But this is surely "fair-weather" liquidity, since "no one would seriously defend the proposition that all things should be made liquid" (Simmons 1947).

Andrew Haldane (2012) adds that "cycles in money and banking credit were indeed familiar from centuries past" and yet, for some odd reasons, these insights were ignored for perhaps a generation, with near-fatal consequences for us all. Investors and firms did not expect asset market liquidity to be impaired or funding disruptions to last for so long (Senior Supervisor Group Report 2008). The sudden collapse in liquidity conditions when the Reserve Primary Fund "broke the buck" in September 2008 came as a big surprise and market stability was only restored after central banks intervened with unprecedented liquidity support.

Former Federal Reserve Chair Ben Bernanke has recently observed that the financial crisis can best be understood as "a classic financial panic transposed into the novel institutional context of the 21st century financial system" (Bernanke 2013). He draws our attention in particular to the Panic of 1907, when financial innovations gradually undermined the coordinating role of the clearinghouse and lightly regulated trust companies were used to 
circumvent reserve requirements. When investors realized that the market was overextended, there was a sudden rush to realize positions, leading to fires sales and further losses. A steep decline in interbank lending was important in both episodes. And, much of the panic occurred outside the traditional banking system, in the so-called shadow-banking sector (ibid.)

The perception that claims on trust companies (or shadow banks) were as good as cash was based on explicit or implicit promises by their sponsors to provide liquidity and credit support. Or the perception was based on the high ratings of the securitized assets on their balance sheets (Tarullo 2013). But as a BIS report noted twenty-five years ago (BIS 1986):

The presumed superior liquidity of securitized assets over conventional bank loans may turn out to be a mirage if a substantial number of the creditors attempt to liquidate their holdings simultaneously.

The resulting fire sales in 2008 resembled the panic liquidation by trust companies in 1907. The sudden withdrawal of funding led to rapid deleveraging and "repo runs." Fire sales of securities into falling markets created adverse feedback loops of mark-to-market losses, margin calls, and further liquidations. This "unwinding of the risk illusion, that is, the assumption that lending to shadow banks was essentially risk-free, helped transform a dramatic correction in real estate valuations into a crisis that engulfed the entire economy“ (Tarullo 2013).

The crisis has led to a greater awareness of the potential fragility of our financial system and the need to protect financial stability; "liquidity fears have put regulators on the offensive." 5 And as Gillian Tett observed in the Financial Times (Tett 2013): "Today everyone knows liquidity can vanish, usually when most needed."6 The same observation was made during the crisis by Willem Buiter: "The liquidity of markets is rarely a deep, structural characteristic, but the endogenous outcome of the interaction of many partially and poorly informed would-be buyers and sellers. Market liquidity can vanish at short notice, just like funding liquidity" (Buiter 2008).

\footnotetext{
${ }^{5}$ Financial Times, November 18, 2013

${ }^{6}$ C. Borio (2004) explored the anatomy of market distress and vanishing liquidity in a 2004 BIS WP, as well as the policy options to address it, i.e. well before the recent financial crisis
} 
This endogenous nature of private credit (and liquidity) was not sufficiently appreciated before the crisis. Inside money expands like ripples in the pond during the upswing on the back of private promises to pay (back). ${ }^{7}$ As Hayek observed in 1931, "the characteristic peculiarity of these circulating forms of credit is that they spring up without being subject to any central control, but once they have come into existence their convertibility into other forms of money must be possible if a collapse of credit is to be avoided" (Hayek 1931).

This convertibility of inside money (bank money) into outside money (cash) is achieved when central banks intervene in a crisis to support vanishing market liquidity. But how far should central bank stretch their balance sheet to support liquidity in these private, spontaneous markets? This becomes a pressing question when markets have grown at an exponential pace, like the repo and over-the-counter (OTC) derivatives markets. Should taxpayers' monies be put at risk to support a financial system with "excess credit elasticity"? ${ }^{8}$

\section{The Challenge of Endogenous Finance}

The rapid growth of shadow banking has challenged the traditional view of banking where banks would receive savings and then intermediate it towards the most productive uses. Banks were supposed to receive a tangible "good" — savings — and pass it on to the investor; nothing was lost in the process. The alternative, and more realistic, view of banking now recognizes that “banks can create money out of nothing” (Borio 2012, Turner 2013). It then follows logically that privately created money can disappear as well. As Adrian and Shin (2009a) note, “... when liquidity dries up, it disappears altogether rather than being re-allocated elsewhere."

The global financial crisis showed how funding and market liquidity interacted to support rapid growth in credit and asset markets, but also how fast this liquidity can disappear. The shadow banking system became a key provider of funding liquidity to both financial institutions and market makers (FSB 2013b). Shadow banking activities was indeed central to the provision of liquidity in core funding markets. These core markets underpin the liquidity creation process within the financial system itself, and a failure could easily lead to a "liquidity spiral" and a generalized liquidity crisis (Johnson and Santor 2013).

\footnotetext{
${ }^{7}$ See Gurley and Shaw (1960) for the distinction between inside and outside money

${ }^{8}$ Borio and Disyatat (2011) introduced the term "excess elasticity" of the financial system 
Global liquidity is today highly influenced by this interplay between banks and non-bank financial institutions and the ebb and flows of risk perceptions in global financial markets (BIS 2011). International bank credit exhibits strong boom-bust cycles that appear to correspond closely to episodes of financial distress, and periods of strong growth in cross-border credit are often characterized by elevated risk appetite. This "self-reinforcing interaction between risk appetite and liquidity is not yet sufficiently appreciated" (Cœuré 2012), even though it is quite clear that private liquidity has become highly endogenous to the conditions in the global financial system.

The pro-cyclical nature of bank credit and the interaction with the shadow banking system has been studied intensively since the global financial crisis. Since the seminal paper on the shadow banking system by Pozsar et al. (2010), a range of other in-depth studies on shadow banking, the repurchase market and securities lending has followed. Through this more recent work, we have gained a better understanding of the "repo machine" that was at the center of the financial crisis in the US.

Adrian and Shin (2009b) explore the hypothesis that "the financial intermediary sector, far from being passive, is instead the engine that drives the boom-bust cycle." Rather than looking at how financial frictions might affect the real economy, they go straight to the financial sector and try to understand how finance became the propagator of the crisis instead of a conduit for prosperity. They note that securitization was intended to disperse risks associated with bank lending so that investors who were better able to absorb losses would share the risks (2009a):

But in reality, securitization worked to concentrate risks in the banking sector. There was a simple reason for this. Banks and other intermediaries wanted to increase their leverage - to become more indebted-so as to spice up their short-term profit. So, rather than dispersing risks evenly throughout the economy, banks and other intermediaries bought each other's securities with borrowed money. As a result, far from dispersing risks, securitization had the perverse effect of concentrating all the risks in the banking system itself. 
Hyman Minsky described this pro-cyclical nature of financial markets long before the recent financial crisis. He noted: "Securitization implies that there is no limit to bank initiative in creating credits, for there is no recourse to bank capital" (Minsky 1987). This makes the supply of credit almost infinitely elastic as every new "euphoric era means that an investment boom is combined with pervasive liquidity-decreasing portfolio transformations" (Minsky 1982, and also Borio 2013 on the "excess elasticity" of the financial system).

The more recent experience with quantitative easing $(\mathrm{QE})$ has shown that bank credit is quite autonomous and difficult to influence, as the link between bank credit and central bank money is very weak. Private liquidity tends to move quite independently of the prevailing stance of monetary policy, reflecting private sector risk perceptions ("the risk channel") and the ease of arranging non-bank financing (via the "shadow banking infrastructure"). These liquidity cycles are then amplified by the rise and fall in collateral prices, which again propagate through the collateral chains of the shadow banking system. Banks and shadow banks are not just allocating pre-existing savings; collectively they create both credit and deposits (Turner 2012). Their cyclical behaviour is now at the heart of the more violent swings in the financial cycles that we have experienced over the last two decades.

This new financial landscape requires a reorientation in both theory and policy. Before the crisis, money and credit were seen as either redundant or at least inessential in the mainstream New Keynesian paradigm (Borio and Disyatat 2010). Standard models were based on one representative, risk-less agent, so anyone's IOU could and would be immediately and fully acceptable in payment for goods or services" (Goodhart and Tsomocos 2011). There was no need for money! Building new models that capture the interaction between the financial and the real sectors and the role of credit should now be a key preoccupation of academics and policymakers. This may require some novel approaches, as mainstream theory needs to interact with and build on insights from non-traditional schools of thought. As Borio and Disyatat (2011, p. 31) note, a deeper understanding of financial crises and the workings of our modern financebased global economy will require "a rediscovery of the essence of monetary analysis."

Fortunately, there is a rich theoretical tradition dealing with the instability of financial markets that can be tapped to improve our understanding of modern capitalist economies with banks, finance, and credit. One major contributor is Hyman Minsky, who built his financial instability theory on the back of J. M. Keynes's deep insights into the working of a modern monetary economy. According to Martin Wolf of the Financial Times, "His masterpiece 
Stabilizing an Unstable Economy, provides incomparably the best account of why the mainstream theory is wrong," i.e., that the modern capitalist economy is inherently stable:

Periods of stability and prosperity sow the seeds of their downfall. The leveraging of returns, principally by borrowing, is then viewed as a certain route to wealth. Those engaged in the financial system create - and profit greatly from-such leverage. When people underestimate perils, as they do in good times, leverage explodes. ${ }^{9}$

No wonder that former Fed Chairman Alan Greenspan admitted "shocked disbelief" while watching his "whole intellectual edifice collapse in the summer of 2007" and that he confessed that he had "put too much faith in the self-correcting power of free markets." 10 And he added: “ $\ldots$ the immense and largely unregulated business of spreading financial risk widely, through the use of exotic financial instruments called derivatives, had gotten out of control and had added to the havoc of the crisis."

The increased pro-cyclicality of the financial system has led to a reorientation in policy. In addition to policy measures aimed at strengthening the robustness of financial institutions, there is now a greater willingness to address the endogenous credit cycles more directly. Macroprudential instruments will be targeted at excessive credit growth and central banks and supervisory authorities will work together to improve underwriting standards (IMF 2013). In addition, there is also a greater willingness among policymakers to intervene in the free workings of financial markets, as "markets are no longer viewed as self-stabilizing" (Tett 2013). Even structural solutions are no longer taboo and governments (belatedly) now want to create some controls on shadow banks (ibid.).

It remains to be seen if the proposed reforms will be enough to dampen the endogenous cycles of finance. The extraordinary expansion of shadow banking credit is still supported by the preferential treatment of repo and derivative transactions under bankruptcy law (Perotti 2012, 2013). ${ }^{11}$ And lax rehypothecation rules still encourage the build-up of collateral chains that propagate failure between key actors in core funding markets. As noted above, such breakdowns in market liquidity could again lead to pressure for central bank interventions.

\footnotetext{
${ }^{9}$ Martin Wolf, "Seven ways to fix the system's flaws," Financial Times, January 22, 2012

${ }^{10}$ Quoted in NY Times, October 23, 2008. Greenspan's testimony is also included in the recent film "Money for Nothing"; see http://moneyfornothingthemovie.org

${ }^{11}$ Without this "safe harbour" protection, a party to a repo contract would be a regular debtor in a bankruptcy proceedings
} 
Central banks' liquidity policies are thus closely related to the developments in the shadow banking sector and the "changing collateral space" (Singh 2013a).

\section{Shadow Banking and Collateral Pressures}

The shadow banking sector is both a user of collateral and a collateral provider. As Manmohan Singh of the IMF has argued in several papers, shadow banking is really a network of collateral transactions that today constitutes our modern financial system (Singh 2012, 2013a). This "collateral landscape" is now changing due to regulatory initiatives and the general move towards more secured financial transactions. The result is a scramble for safe assets and increasing concerns about collateral shortages in the future (IMF 2012).

The increased preference for collateralized transactions has led to asset encumbrance of banks' balance sheets (BIS 2013a, EBA 2013). Banks try to secure cheaper funding by offering collateral for new loans. Examples of such secured funding include covered bonds, repurchase agreements and derivatives trades. But the sum total is too many claims against the banking sector's aggregate balance sheet, concern about too much asset encumbrance and a markedly weakened position for unsecured creditors, including non-guaranteed depositors.

The scale of this extra demand for collateral is not yet known, but estimates vary from two to six trillion dollars (IMF 2012, Hauser 2013, and US Treasury 2013)! The new liquidity rules for banks under the Basel 3 agreement (LCR and NSFR) add somewhere between one to 2.5 trillion dollars in demand for high-quality liquid assets (HQLA). Then there is the additional demand coming from the new derivatives regulation, where counterparties will have to post HQLA for the default fund (initial margin) and variation margins. This might add another one to two trillion in HQLA demand. ${ }^{12}$ In addition, banks will have to provide far more collateral for their remaining bilateral derivatives trades, with estimates varying between another one and two trillion dollars. $^{13}$

Several reports have recently analysed the potential shortages of highly liquid collateral (IMF 2012, BIS 2013b). Many argue that there will not be a shortage of HQLA, since primary issuance is expected to remain fairly high going forward (US Treasury 2013). However, there could be scarcity of HQLA, especially if markets become stressed again (BIS 2013a).

\footnotetext{
${ }^{12}$ Proposed limitations on rehypothecation will "freeze" collateral, thereby eliminating its velocity entirely (see US Treasury TBAC presentation Q2 2013 for details)

${ }^{13}$ Note that these estimates are for "normal" market conditions. In stressed markets the demand for HQLA would increase substantially
} 
The scale of the required collateral (for bilateral and CCP margins) in the OTC markets is also highly uncertain. These markets are huge, estimated by the BIS to almost $\$ 700$ trillion (in notional amounts outstanding) in June 2013 (BIS 2013c). ${ }^{14}$ The concentration is also very high in these markets, with a few international dealers holding up to 60-70 percent of all outstanding contracts (Smyth and Wetherilt 2011, OCC 2013). This concentration creates risk of rapid propagation of distress across the financial system should any one of these major dealers become distressed. In addition, the widespread use of rehypothecation and margining is amplifying the pro-cyclicality of the financial system (Deryugina 2013, Sidanius and Zikes 2012).

There is indeed concern that tighter market conditions for safe assets could impact financial stability (IMF 2012). As investors search for higher quality liquid assets, there could be more short-term market volatility, herding behaviour and sharp price movements. Tying up high-quality collateral in CCP guarantee funds and initial margins could also reduce liquidity in the derivatives and repo markets, and lead to increased risk of price spikes and shortages of high-grade collateral (ibid).

The effectiveness of netting and the size of net exposures will determine the final demand for HQLA. There will surely be effects on pricing, market structure and the workings of markets more broadly (Heath et al. 2013). But the true level of asset encumbrance and the risk it poses for banks is so far unknown, and the financial stability implications of increased collateralization of financial transactions and rising asset encumbrance levels remain poorly understood (Gai et al 2013).

One predictable effect of the upcoming scramble for HQLA is "collateral transformation services" that can expand the HQLA universe. These could take the form of collateral mobilization (from insurance companies and pension funds), increased collateral velocity (i.e. re-use), collateral pooling (among firms in the same company) or the re-emergence of asset creation (creating "HQLA" as was customary before the recent crisis) (Hauser 2013). There will be a huge market for collateral upgrading, by connecting those with good collateral with, for example, a hedge fund that does not have good collateral but needs it to post initial margin with a CCP.

\footnotetext{
${ }^{14}$ The gross market value is far less, around $\$ 20$ trillion, whereas gross credit exposure - after netting - is around $\$ 4$ trillion (BIS 2013c)
} 
Such a development is even supported by regulators; Board member Benoît Cœuré from the European Central Bank (ECB) recently encouraged market participants to analyse solutions that optimize the use of collateral (Cœure 2013). And the IMF proposes "some flexibility in the definition of acceptable safe assets" to avoid undue pressure in the market (IMF 2012), while the ESRB notes that there is a clear incentive for a more prominent role for collateral transformation services to emerge in one form or another (ESRB 2013). The downside of such transformation is, however, more interconnections between key players in the financial market and increased risk of contagion. As M. Singh (2013b) notes: "Collateral transformation is likely to fill the void, but will increase the nexus between banks and non-banks." And these new interconnections between financial institutions will weaken the resilience of the financial system in adverse conditions (Heath et al 2013). Policymakers therefore need to strike a balance between the desire to ensure the soundness of financial institutions and the costs associated with a potentially too-rapid acquisition of safe assets to meet this goal (IMF 2012).

This concern with shortages or scarcity of HQLA has recently led to increased pressure on central banks to relax their liquidity policies; banks want cheaper funding and wider collateral pools. Banks also want to include central bank liquidity facilities in their pool of liquid assets under the new Basel LCR liquidity regulation. Such "Committed Liquidity Facilities" (CLF) could potentially reduce the banks' need for mobilizing new HQLA. But it would surely undermine the spirit of the Basel liquidity proposal (Schmitz 2013), except in jurisdictions that are short of sovereign debt (Stein 2013a).

The new collateral-intensive financial system confronts central banks and governments with a deeply political question: How to manage the potential systemic risk generated by the shadow banking system, especially in times of stress (Gabor 2013)? As regulators try to instill more safety in the system, transaction costs will increase, prices go up and volumes fall. But scaling back the profitable OTC market may be like putting the genie back in the bottle. The current pushback from the financial industry over the proposed OTC reforms shows that this will be a tough battle. ${ }^{15}$ And the new market equilibrium for highly liquid assets is indeed "hard to fully fathom in advance" (Stein 2013a).

\footnotetext{
15 Financial Times: Banks benefit after Basel liquidity rules loosened, January 11, 2013 notes that the last adjustments in the liquidity rules reduced the largest US banks' need for liquid assets from $\$ 840 \mathrm{bn}$ to $\$ 192 \mathrm{bn}$; see also Financial Times: Banks win Basel concessions on debt rules, January 13, 2014 on the recent tweaking of the leverage ratio regulation
} 
There is also the risk that pressure to securitize the huge unsecured repo- and OTC positions may expose clearing agents (CCP) to new and unexplored concentration risk. This could put pressure on central banks to provide even more liquidity in a crisis to avoid a new systemic meltdown (Murphy 2013, Tucker 2014). ${ }^{16}$ And increased collateral requirements would also expose the financial system to pro-cyclical and self-reinforcing spirals as market participants will repo, swap or sell assets to meet collateral calls in times of stress (ESRB 2013).

The huge scale of the collateral based shadow banking system represents a dilemma for central banks (Moe 2012). Unless the endogenous growth in shadow banking liabilities is somehow constrained, there will continue to be pressure on central banks to stop fire sales and create outside liquidity in periods of stress (Perotti 2012, Mehrling 2013). To prevent the new Basel liquidity regulations (LCR and NSFR) from "dissolving from within" (Schmitz 2013), it is important that central banks review their liquidity policies carefully and avoid relaxing their lending standards further (Goodfriend 2012). With many sovereigns under pressure due to weak fiscal positions and low economic growth, central banks cannot afford to be lax in their provision of central bank money. Faced with a shadow banking system with "excess elasticity" (Borio 2013), central banks should limit their liquidity support to further market-based finance, and instead support real structural reforms that can reduce the need for massive liquidity assistance in the future. ${ }^{17}$

\section{Collateral Dilemmas}

Central banks' liquidity policies were transformed during and after the financial crisis. When Lehman failed and AIG had to be rescued soon after, financial markets were severely distressed. The risk of a worldwide systemic crisis was considered by many to be very real. Against this background many central banks initiated new and innovative liquidity facilities to provide liquidity to a wider set of counterparties, at much longer maturities and against a gradually much wider set of collateral. ${ }^{18}$ Without this timely liquidity support, the breakdown in market liquidity would most likely have led to the disorderly failure of a number of major financial institutions.

\footnotetext{
${ }^{16}$ Murphy (2013) notes that "without access to a central bank, a CCP could find itself unable to fund itself in the event of a crisis"

${ }^{17}$ See (EU 2014a) for the new structural reform proposal from the European Commission in response to the Likaanen report (Likaanen 2012)

${ }^{18}$ Madigan (2009) provides the rationale for the new liquidity policies of the Federal Reserve during the crisis
} 
Ben Bernanke (2013) has argued that this expanded role for the Federal Reserve in liquidity provision was a natural extension of the classical lender-of-last policy prescribed by Walter Bagehot. ${ }^{19}$ "The Fed lent not only to banks, but, seeking to stem the panic in wholesale funding markets, it also extended its lender-of-last-resort facilities to support nonbank institutions, such as investment banks and money market funds, and key financial markets, such as those for commercial paper and asset-backed securities (ibid.)." The scale of liquidity support was massive, as "the Fed's balance sheet was being used to directly replace the decline in balance sheet capacity of the financial intermediary sector" (Adrian and Shin 2009a).

The huge increase in central banks' balance sheets obviously led to changes in their collateral policies. In principle, central bank credit should only be granted to solvent firms against good collateral. ${ }^{20}$ This would act as a safeguard against reckless money growth, limit the central bank's exposure to financial loss and lessen the need for counterparty credit assessment (Cheun, 2009). A shortage of eligible collateral would then act as a brake on central bank credit, acting as an anchor much like gold under the gold system of international finance. A strict collateral policy would in this way help in preserving the integrity of the fiat money system. Central banks should only extend credit backed by "real value assets." 21

Central banks are therefore normally by law prevented from issuing (central bank or outside) money without some sort of collateral backing. The issuance of claims against oneself is in principle indefinitely augmentable and therefore not well qualified as collateral. The same goes for government credit, as the government could then pledge self-issued debt as collateral for loans from the central bank. The central bank can, however, issue new money against government securities purchased in the secondary market for monetary policy purposes (Jácome et. al., 2012). Thus, government securities provided by third parties are normally considered HQLA. ${ }^{22}$

But the breakdown in unsecured interbank credit after the crisis put commercial banks in a squeeze. Their own liquidity needs increased dramatically, while their counterparties at the

\footnotetext{
${ }^{19}$ The Bagehot Rule (Bagehot 1873) states that central banks should lend early and freely to solvent firms against good collateral and at high rates

${ }^{20}$ How to determine if a counterparty is indeed solvent is an equally challenging task, ref. Stein (2013a): "The line between illiquidity and insolvency is far blurrier in real life than it is sometimes assumed to be in theory"

${ }^{21}$ See Lehmbecker (2008) for a statement of the German Property School of Economics' view on collateralized money

${ }^{22}$ With the recent financial crisis in the EU, there is now a discussion about the credit quality of sovereign debt of countries without their own central bank
} 
same time withdrew their posted collateral. In response, central banks relaxed their traditional strict collateral requirements in order to accommodate the bank's desperate need for liquidity. And banks became more creative in finding ways to post low quality, but acceptable collateral at the central bank, because better quality collateral had alternative uses with better returns. This type of behaviour was well known even before the crisis, as observed by an ECB executive board member (quoted in Chailloux et al., 2008, p.5): ${ }^{23}$

Quite understandably, (central bank counterparties) have economized on the use of central government bonds which has been often almost the only collateral counterparties could still use in interbank repo markets. Instead they have brought forward less liquid collateral...including ABSs, for which primary and secondary markets have basically dried up.

By facilitating this type of "collateral manufacturing" central banks' collateral policies facilitated the build-up of leverage before the crisis in the banking and the shadow banking systems. Banks could use their high quality collateral to obtain repo-financing, thereby providing pledgeable collateral for the daisy chains of rehypothecation in the shadow banking system. By running an accommodative collateral policy before the crisis, many central banks supported the excessive market growth that they eventually had to support during the crisis with even more relaxed collateral standards.

The recent changes in collateral policies of the Bank of England can be seen as a natural extension of this accommodative liquidity policy (BoE 2013). The new Governor announced the policy by noting: "We are open for business" (Carney 2013). Facilities will in the future be on longer terms; the range of assets accepted as collateral will be wider, including raw loans if required; all facilities will be cheaper, and there will also be foreign exchange liquidity lines, based on international swap lines (ibid.).

${ }^{23}$ José Manuel González-Páramo, ECB Executive Board Member, June, 2008 
This new liquidity policy is consistent with the Governor's long held position that "in times of crisis central banks must act as a market-maker of last resort, by becoming a counterparty to major market participants" (Carney 2008). But embracing this expanded role also carries certain risks. As Martin Wolf noted after the new BoE policy was announced: ${ }^{24}$

A central bank can in principle create domestic money without limit. But if it uses that power more freely, it will encourage banks and markets to generate more maturity transformation, making themselves and the economy more vulnerable to panic.

Central banks are thus faced with an inherent tension between the markets need for liquidity in times of crisis and the strictures of their own collateral rules. As Zorn and Garcia (2011) from the Bank of Canada noted:

The benefits of a flexible collateral policy were demonstrated during the crisis, but how flexible should collateral policies be? How much risk can or should a central bank take on? How can operational readiness to accommodate this flexibility be balanced with the costs, particularly when extraordinary events are, by definition, infrequent?

If banks perceive the central bank's collateral policy in a (new) crisis correctly, they may well hold less of the good collateral and more of the bad (a form of Gresham's law). And the central bank may not be able to stick to their announced strict collateral policy, just as the banks suspected. As Paul Tucker noted (2009): "In other words, a central bank policy of lending against only the best assets is likely to prove time inconsistent when it comes to the crunch."

If central banks insist on only highly liquid assets as collateral for liquidity support in a crisis, some otherwise solvent banks with liquidity problems may fail. This is obviously a policy dilemma for central banks. They risk amplifying the financial crisis by tightening their lending standards during a crisis. This is obviously counterintuitive, as they are supposed to rescue the financial markets in a crisis. But it illustrates well the tensions between "finance based" collateral guidelines and "macro based" crisis management policies. A countercyclical collateral policy could indeed be useful in dampening the financial cycle and provide some funding

\footnotetext{
${ }^{24}$ Martin Wolf: Bank of England's Mark Carney places a bet on big finance. Financial Times, October 29, 2013
} 
alternatives when conditions in the market become tight and build an illiquidity discount into some asset prices" (Chailloux et al. 2008). However, such countercyclical behaviour can only be viable if "collateral neutrality" is restored in normal times. "Otherwise, central banks would increasingly ease their collateral requirements and end up undermining public confidence in the soundness of their balance sheet, potentially weakening the trust in money" (ibid.).

Going forward, central bank collateral policy will have to grapple with these conflicting goals. Central bank collateral policy should also be integrated with the broader policy shift towards macro-prudential policy (Allen 2013). Central bank collateral policy will be important not only for short-term liquidity policy, but also for the longer-term development of core funding markets. Somehow they will have to decide which funding markets are systemic and how far they should go in accommodating the endogenous growth of shadow bank liabilities?

\section{Policy Challenges}

The global financial crisis forced central banks to extend the scope and scale of their traditional role as lenders of last resort. They broadened their liquidity support to non-deposit-taking institutions and intervened directly in a broad range of asset markets related to shadow banking activities. Some would like to see central banks embrace this new role as market maker of last resort (Mehrling 2011), while others are uncomfortable with the longer-term implications of the recent sharp expansion in central banks' balance sheets (Caruana 2011).

The current policy discussion relates to fundamental principles of central banking. According to Andrew Sheng, "at the heart of the current debate is whether central banks, as agents for monetary discipline, should re-impose the hard budget constraint on global fiat money and by what rule" (Sheng 2011).

But is it reasonable for central banks to impose strict limits on their official liquidity support when private credit remains largely unconstrained? As Borio and Disyatat (2011) have noted:

The fundamental weaknesses in the international monetary and financial system stem from the problem of 'excess elasticity': the system lacks sufficiently strong anchors to prevent the build-up of unsustainable booms in credit and asset prices (financial imbalances) which can eventually lead to serious financial strains and derail the world economy. 
We should therefore start by exploring ways to limit the unconstrained growth of shadow banking liquidity creation before we impose severe limitations on central bank official liquidity. After all, the provision of an elastic (official) currency is one of the key functions of central banks in a crisis. We therefore need to find the right balance between the legitimate need for market liquidity support in a crisis and unwarranted central bank support for purely speculative credit creation. $^{25}$

The sharp growth in shadow banking activities combined with a shift from unsecured to secured credit has created pressure on HQLA and central bank liquidity facilities. The new focus on asset encumbrance is just a reflection of this sharp growth, as unsecured creditors collectively try to protect their positions. But this rush to safety cannot remove the aggregate risk in the financial system, so we have a classic case of "fallacy of composition": What may be individually rational can produce bad collective outcomes. We need to find a better balance between the growth of finance, secured and unsecured funding, and central banks liquidity facilities.

Limiting the growth of the shadow banking system is one key element in this new balance. As Borio (2013) notes: "The Achilles heel of the international monetary and financial system is not so much the risk of a structural - excess demand for safe assets", but rather the "excess elasticity" of the same system, i.e. the inability of policy regimes in place - monetary, prudential and fiscal - to prevent successive financial boom and bust cycles.

Reforming the non-bank financial sector has been high on the policy agenda for quite some time. After the crisis, the G20 leaders agreed to deal with the fault lines exposed by the crisis in the "shadow banking system". Their focus has been on the excessive reliance on shortterm wholesale funding (money-market funds), the growth of repo and securities lending transactions, and the general lack of transparency that hid growing amounts of leverage and mismatch between long-term credit extension and short-term funding (FSB 2013).

The European Commission has followed up with a proposal to improve the transparency of securities financing transactions (EU 2014b). This proposal will increase the reporting requirements of such transactions and allow supervisors to better identify the links between banks and shadow banking entities. The Commission also wants to improve the transparency of

${ }^{25}$ There is a growing consensus that financial deepening is not always a good thing (see Cecchetti and Kharroubi 2012) 
the rehypothecation activity and impose minimum conditions to be met by the parties involved. $^{26}$ It remains to be seen if these proposals will be sufficient to stem the growth of nonbank finance and remove the current opaqueness in the shadow-banking sector.

As long as the underlying incentives are strongly supportive of continued growth in nonbank credit, in large part due to low risk weights and the preferential status of collateral-based credit transactions, the reporting requirement may well be in vain (Perotti 2014). Sheila Bair (2013) is blunter when she notes: "Repos among financial institutions are treated as extremely low risk, even though excessive reliance on repo funding almost brought our system down. How dumb is that?" Central banks will therefore continue to be under pressure "to stop fire sales and create outside liquidity" in a crisis (Perotti 2012), and banks will argue that "diminishing the repo market could reduce liquidity in the assets that are loaned out, such as government bonds and even stocks." 27 As the pressure builds, central bankers have already conceded that the definition of HQLA could be relaxed or that CLF-type mechanisms could be adopted. Governor Stein of the Federal Reserve notes: "It is worth keeping an open mind about more widespread use of CLF-like mechanisms" (Stein 2013a):

If a scarcity of HQLA-eligible assets turns out to be more of a problem than we expect, something along those lines has the potential to be a useful safety valve, as it puts a cap on the cost of liquidity regulation. Such a safety valve would have a direct economic benefit, in the sense of preventing the burden of regulation from getting unduly heavy in any one country.

Some would also like to see central banks talking on a wider role as "market maker of last resort." Mehrling et al. (2012) argue that "central banks have the power and responsibility to support the shadow banking markets in times of crisis as well as in normal times." They argue that the private collateral-based credit system is a natural extension of the existing national credit systems, and that the international dollar money market has in fact become the funding market for all credit needs today, both private and public. Supporting this new dealer system of finance should, in their view, be the new role for central banks operating in the spirit of Bagehot. As Allen (2013) also notes: "The hard truth, as Bagehot pointed out, is that in a

\footnotetext{
${ }^{26}$ On 29 January 2014, the European Commission also adopted a proposal for a regulation to stop the biggest banks from engaging in proprietary trading and to give supervisors the power to require those banks to separate other risky trading activities from their deposit-taking business (EU 2014a)

${ }^{27}$ Financial Times: Repo market clampdown could hurt, August 29, 2013
} 
liquidity emergency, a central bank has to be ready to lend, possibly in large amounts, and against a wide range of collateral."

The question is again how far central banks should go in embracing this potentially costly function? Johnson and Santor (2013) from the Bank of Canada support this new MMLR function, since some core funding markets now are so critical for our financial system that "a shock could have catastrophic consequences." If funding liquidity vanished, there would simply not be any substitutes. These funding markets therefore need to be "continuously open even under stress" (Carney 2008). As a consequence, central bank support should be permanently available and the traditional lender-of-last-resort function should be expanded to include support of core funding markets, "with the central bank being a 'market maker' of last resort if necessary" (Johnson and Santor 2013).

However, before venturing into this uncharted territory of market making of last resort, some more analysis should be conducted on which markets are especially important to the real economy, or to the financial system itself; and what qualities those markets need to avoid egregious risks to stability (Tucker 2014). We simply need a solid debate about central banks' role in supporting financial markets. According to Paul Tucker, we need a better framework for discussing the robustness of market and funding liquidity, whether there are ready substitutes if a market should close, and about the resilience of liquidity in systemically relevant markets. Such a framework "would have focused policymakers' attention on the workings of the ABS markets and, in particular, on the associated repo markets well before the crisis" (ibid.).

On the other hand, one could argue that it is not the job of central banks to decide how big the financial sector should be or which markets should be supported or not. Our job is just to ensure that the financial system is safe, as stated by the Governor of Bank of England (Carney 2013); "the Bank stands ready to provide solvent counterparties with highly liquid assets in exchange for a wide range of collateral assets of good credit quality but lower market liquidity." But this is exactly the sticking point: When is a counterparty solvent and how far should the bank be stretching its collateral criteria, assuming the counterparty is solvent? ${ }^{28}$

\footnotetext{
${ }^{28}$ The BoE argument seem to be that as long as the counterparty is considered solvent, it is fair to accept "even raw loans" as collateral for liquidity support
} 
It is well known that the determination of solvency in a crisis is always tricky and subject to subjective judgments. As Governor Stein notes (Stein 2013a):

A key point in this regard--and one that has been reinforced by the experience of the past several years--is that the line between illiquidity and insolvency is far blurrier in real life than it is sometimes assumed to be in theory. Indeed, one might argue that a bank or broker-dealer that experiences a liquidity crunch must have some probability of having solvency problems as well; otherwise, it is hard to see why it could not attract short-term funding from the private market.

When a central bank acts as a lender of last resort in a crisis, it necessarily takes on some credit risk. And if it experiences losses, these losses will ultimately fall on the shoulders of taxpayers. So is relaxing collateral standards with reference to the presumed solvency of counterparties in a crisis perhaps not the best of arguments? There is a distinct possibility that central banks will then be subject to the "time inconsistency" of their collateral policies, as they relax collateral requirements for presumed solvent counterparties, in order to support vanishing funding liquidity in systemic, core financial markets.

A better policy would be to add conditions to such liquidity support. Hyman Minsky (1985) supported an elastic currency in the midst of a crisis (when all other options had been exhausted), but suggested that such a flexible liquidity policy should be combined with tough regulatory measures both before and after the crisis: "Clearly, central bank lender-of-last-resort interventions must lead to legislated or administered changes that favour hedge financing and ... the central bank should continuously 'lean against' the use of speculative and Ponzi financing" (ibid). ${ }^{29}$

Central bank liquidity support should not be made available for core funding markets without a solid test of their integrity and robustness. And structural reforms should also be considered to bring better balance between the size of the shadow banking activities and central banks' capacity and willingness to provide backup liquidity. "The idea that a huge expansion even of a reformed financial system would bring great global benefit is doubtful" (Wolf 2013) and "even right-wing voices now think it make sense to restrict the size and behaviour of banks" (Turner 2013). Such policy measures would be in line with recent research that finds that

\footnotetext{
${ }^{29}$ Note that Minsky here anticipated the recent macroprudential policy trend of "leaning against the wind" by some thirty years!
} 
"financial development is good only up to a point, after which it becomes a drag on growth" (Cecchetti and Kharroubi 2012).

Unless the endogenous creation of shadow banking credit is somehow constrained (especially the exponential growth of OTC derivative and repo markets), growing debt will eventually outpace by far the available pool of HQLA. It is vital to strengthen the robustness of core funding markets now, when markets are calm, in order to improve their resiliency before the next crisis occurs. "This is especially important in light of the heightened threshold established by the Dodd-Frank Act for future central bank interventions in the event of a market disruption (Dudley 2013)."

We need to establish a sound system of credit creation reflecting the real economy's need for finance. The current shadow banking system backed by highly volatile collateral values has made our whole financial system more fragile. "If credit creation left to itself goes beyond optimal levels, constraining it may be beneficial" (Turner 2013).

Today, there is an increasing consensus that we need to take financial booms and busts financial cycles - more systematically into account and that central banks should lean more deliberately against booms and ease less aggressively during busts (Borio 2014). But so far there have been few concrete suggestions for limiting the strong credit growth in the shadow banking system. ${ }^{30}$ And the dynamics of endogenous finance are still inadequately explained in mainstream theory compared to the classic accounts of Keynes (1936), Simons (1936) and Minsky (1982). They directed us to the critical importance of controlling "near-moneys," especially in the upswing. Since the capitalist economy is inherently unstable, and the shadowbanking sector is an important source of this instability, we will need stronger medicine than just "leaning against the wind." As H. Simons (1936) suggested, only radical changes in the financial sector's structure can prevent future crises (Moe 2013).

Central banks should be especially concerned about providing support to core financial markets without any form of structural reform. A judicious review of the robustness of such markets is at least needed before central banks commit fully to such a new and expanded role as liquidity provider. Until it can be shown that these markets are reasonably able to stand on their

\footnotetext{
${ }^{30}$ The emphasis so far is on data collection and better monitoring; this will improve our knowledge of the interconnections, but can surely only be a first step?
} 
own without central bank support in a crisis, authorities should insist on further reforms. ${ }^{31}$ It would indeed be ironic if central banks declared victory in the fight against too-big-to-fail institutions, just to end up bankrolling core funding markets. ${ }^{32}$

${ }^{31}$ The Federal Reserve Bank of New York has long been fighting for structural changes in the tri-party repo market (Stein 2013b) and the Federal Reserve System has been equally vocal in its call for reform of the money-market industry (Federal Reserve 2013). The shift of derivatives positions onto CCPs could also put taxpayers on the hook again for the "reshuffled" OTC positions (Singh 2012)

32 Thomas Baxter, General Counsel of the New York Fed, recently noted that broad based liquidity support, like the Primary Dealer Credit Facility during the crisis, would still be permitted as a form of "macro prudential" policy, while institution-specific liquidity support, like the support for AIG, would be prohibited according to the new Dodd-Frank law (Baxter 2013) 


\section{References}

Adrian, Tobias and Hyun Song Shin. 2009a. "The Shadow Banking System: Implications for Financial Regulation.” Staff Report No. 382. Federal Reserve Bank of New York. 2009b. "Financial Intermediaries and Monetary Economics.” Staff Report No. 398. Federal Reserve Bank of New York. Revised May 2010.

Adrian, Tobias, A. B. Ashcraft and N. Cetorelli. 2013. Shadow Bank Monitoring. Federal Reserve Bank of New York Staff Report No. 638

Allen, William A. 2013. A new and explicit policy on liquidity provision. Centralbanking.com, 28 October 2013

Bagehot, Walter. 1873. Lombard Street: A Description of the Money Market. London, UK: Henry S. King and Co.

Bair, Sheila. 2013. Everything the IMF wanted to know about financial regulation and wasn't afraid to ask. Vox.eu, 9 June 2013

Bank for International Settlements. 1986. Recent innovations in international banking (Cross Report). CGFS Publications No. 1

2011. Global liquidity - concept, measurement and policy implications. CGFS Publications No 45. November 2011

. 2013a. Asset encumbrance, financial reform and the demand for collateral assets. CGFS Papers No 49, May 2013

. 2013b. Macroeconomic impact assessment of OTC derivatives regulatory reforms. August 2013

. 2013c. Statistical Release: OTC derivatives statistics at end-June 2013. Monetary and Economic Department. November 2013

Bank of England. 2013. Liquidity insurance at the Bank of England: developments in the Sterling Monetary Framework. October 2013

Baxter, Thomas C. 2013. From Bagehot to Bernanke and Draghi: Emergency Liquidity, Macroprudential Supervision and the Rediscovery of the Lender of Last Resort Function. Remarks at the Committee on International Monetary Law, Madrid, September 19, 2013

Bernanke, Ben S. 2013. Remarks at Fourteenth Jacques Polak Annual Research Conference, IMF, November 8

Borio, Claudio. 2004. Market distress and vanishing liquidity: anatomy and policy options. BIS Working Papers No 158, July 2004 
. 2012. The financial cycle and macroeconomics: What have we learnt? BIS Working Papers No 395, December 2012

. 2013. Comments on Jean-Pierre Landau's paper. Jackson Hole Symposium, Federal Reserve Bank of Kansas City

. 2014. Monetary policy and financial stability: what role in prevention and recovery? BIS Working Papers No 440. January 2014

Borio, Claudio and P. Disyatat. 2011. "Global Imbalances and the Financial Crisis: Link or No Link?” Working Paper No. 346. Basel, Switzerland. Bank for International Settlements.

Buiter, Willem. 2008. "Central Banks and Financial Crises.” Jackson Hole Symposium, Federal Reserve Bank of Kansas City

Carney, Mark. 2008a. Principles for Liquid Markets. Remarks to the New York Association for Business Economics, New York, 22 May 2008

. 2008b. Building Continuous Markets. Remarks to the Canada - United Kingdom Chamber of Commerce, London, 19 November 2008

2011. Global Liquidity. Remarks to the Canada - United Kingdom Chamber of Commerce, London, 8 November 2011

. 2013. The UK at the heart of a renewed globalization. Speech 24 October 2013

Caruana, Jaime. 2011. "Why Central Bank Balance Sheets Matter." Keynote address at Bank of Thailand-BIS Conference. http://www.bis.org/speeches/sp111216.pdf

Cecchetti, Stephen G and Enisse Kharroubi. 2012. Reassessing the impact of finance on growth. BIS Working Papers No 381

Cetorelli, Nicola and Stavros Peristiani. 2012. The role of banks in asset securitization. Federal Reserve Bank of New York Economic Policy Review 18 (2): 47-64

Chailloux, Alexandre, S. Gray, and R. McCaughrin. 2008. "Central Bank Collateral Frameworks: Principles and Policies.” IMF Working Paper 08/222. Washington, D.C.: International Monetary Fund.

Cheun, Samuel, I. von Köppen-Mertes, and B. Weller. 2009. "The Collateral Frameworks of the Eurosystem, the Federal Reserve system and the Bank of England and the Financial Market Turmoil." ECB Occasional Paper No. 207

Cœuré, Benoît. 2012. "Global Liquidity and Its International Repercussions." Speech at the BIS-ECB Workshop on Global Liquidity and Its International Repercussions. February 6, 2012

. 2013. COGESI workshop on collateral eligibility requirements. Speech 15 July 2013 
Deryugina, Mariya. Standardization of Securities Regulation: Rehypothecation and Securities Commingling in the United States and the United Kingdom. Review of Banking and Financial Law, Vol. 29, Fall 2010 issue, pages 253-288. (September)

Dudley, William C. 2013. Remarks at Workshop on "Fire Sales" as a Driver of Systemic Risk in Tri-Party Repo and Other Secured Funding Markets. October 4, 2013

European Banking Authority (EBA). 2013a. EBA final draft implementing technical standards: On asset encumbrance reporting under Article 100 of Capital Requirements Regulation (CRR). October 30, 2013

European Union/European Commission. 2012. Green Paper - Shadow Banking. 19. March 2012

2013. Communication on Shadow Banking and Proposal on money market funds. 4 September 2013

Structural reform of the EU banking sector. 29 January 2014

2014b. Proposal on transparency of securities financing transactions. 29 January 2014

European Systemic Risk Board (ESRB). 2012. Macroprudential stance on eligible collateral for central counterparties - in response to a consultation by ESMA - based on Article 46 of the EMIR Regulation. 31 July 2012

Federal Reserve Bank of Boston. 2013. The 12 Federal Reserve Bank Presidents Encourage Money Market Mutual Fund Reform; Submit Joint Letter Commenting on the SEC's Proposal. Press Release available at http://www.bostonfed.org/news/press/2013/pr091213.htm

Financial Stability Board. 2011. Shadow Banking: Strengthening Oversight and Regulation. http://www.financialstabilityboard.org/publications/r_111027a.pdf

. 2013a. Strengthening Oversight and Regulation of Shadow Banking; An Overview of Policy Recommendations. http://www.ny.frb.org/research/epr/12v18n2/1207peri.pdf

2013b. Global Shadow Banking Monitoring Report. November 14 http://www.financialstabilityboard.org/publications/r_131114.htm

Gabor, Daniela. 2013. Shadow Interconnectedness: the political economy of (European) shadow banking. In this volume

Gai, Prasanna, Andrew Haldane, Sujit Kapadia and Benjamin Nelson. Bank Funding and Financial Stability. In Heath, Alexandra, Matthew Lilley and Mark Manning. 2013. Liquidity and Funding Markets. Reserve Bank of Australia

Goodfriend, Marvin. 2013. Lessons Learned from a Century of Federal Reserve Last Resort Lending. Testimony before the Subcommittee on Monetary Policy and Trade Committee on Financial Services, U.S. House of Representatives, Washington, D.C. 
Goodhart, Charles A. E. and D. P. Tsomocos. 2011. "The Role of Default in Macroeconomics.” IMES Discussion Paper No. 2011-E-23. Tokyo, Japan: Institute for Monetary and Economic Studies.

Gurley, John G. and E. S. Shaw. 1960. Money in a Theory of Finance. Washington, D.C.: Brookings Institution.

Haldane, Andrew. 2012. What have the economists ever done for us? www.voxeu.com, 1 October 2012

Hauser, Andrew. 2013. The future of repo: 'too much' or 'too little'? Speech given at the ICMA Conference on the Future of the Repo Market, London, June 112013

Hayek, Friedrich A. 1931. Prices and Production Augustus M. Kelly, Publishers, New York; available at http://mises.org/books/pricesproduction.pdf

Heath, Alexandra, G. Kelly and M. Manning. 2013. OTC Derivatives Reform: Netting and Networks. In Heath, Alexandra, Matthew Lilley and Mark Manning. 2013. Liquidity and Funding Markets. Reserve Bank of Australia

International Monetary Fund. 2012. Global Financial Stability Report: Chapter 3: Safe Assets: Financial System Cornerstone?

http://www.imf.org/External/Pubs/FT/GFSR/2012/01/pdf/text.pdf

2013. Key Aspects of Macroprudential Policy. IMF Staff Paper. June 102013. http://www.imf.org/external/np/pp/eng/2013/061013b.pdf

Johnson, Grahame and Eric Santor. 2013. Central Bank Liquidity Provision and Core Funding Markets. In Heath, Alexandra, Matthew Lilley and Mark Manning. 2013. Liquidity and Funding Markets. Reserve Bank of Australia

Jácome, Luis I., M. Matamoros-Indorf, M. Sharma, and S. Townsend. 2012. "Central Bank Credit to the Government: What Can We Learn from International Practices?" IMF Working Paper 12/16. Washington, D.C.: International Monetary Fund.

Keynes, J. M. 1936. The General Theory of Employment, Interest and Money. New York, NY: Harcourt, Brace \& Co.

Lehmbecker, Philipp. 2008. "The Quality of Eligible Collateral and Monetary Stability." Discussion Paper No. 3. Bremen, Germany: Faculty of Business Studies and Economics, University of Bremen

Likaanen, Erkki. 2012. High-level Expert Group on reforming the structure of the EU banking sector, chaired by Erkki Liikanen, 2 October 2012

Madigan, Brian F. 2009. Bagehot's Dictum in Practice: Formulating and Implementing Policies to Combat the Financial Crisis. Jackson Hole Symposium, Federal Reserve Bank of Kansas City 
Mehrling, Perry. 2011. The New Lombard Street: How the Fed Became the Dealer of Last Resort. Princeton, NJ: Princeton University Press.

Mehrling, Perry and Zoltan Pozsar, James Sweeney and Daniel Neilson. 2012. Bagehot was a Shadow Banker: Shadow Banking, Central Banking, and the Future of Global Finance. Mimeo

Minsky, Hyman P. 1982. Can "It" Happen Again? Essays on Instability and Finance. Armonk, NY: M. E. Sharpe.

1985. "Money and the Lender of Last Resort." Challenge 28 (1): 12-18

1987 (2008). "Securitization.” Policy Note. Preface and afterword by L. R. Wray. Annandale-on-Hudson, NY: The Levy Economics Institute of Bard College.

Moe, Thorvald Grung. 2012. Shadow Banking and the Limits of Central Bank Liquidity Support: How to Achieve a Better Balance between Global and Official Liquidity. Working paper No. 712. Annandale-on-Hudson, NY: The Levy Economics Institute of Bard College.

2013. Control of Finance as a Prerequisite for Successful Monetary Policy: A Reinterpretation of Henry Simons' "Rules versus Authorities in Monetary Policy". Accounting, Economics, and Law, De Gruyter, vol. 3(3)

Moreira, Alan and Alexi Savov. 2013. The Macroeconomics of Shadow Banking. August 2013

Murphy, David. 2013. OTC Derivatives, Bilateral Trading and Central Clearing: An Introduction to Regulatory Policy, Market Impact and Systemic Risk. Palgrave McMillan.

Office of the Comptroller of the Currency (OCC). 2013. OCC's Quarterly Report on Bank Trading and Derivatives Activities Second Quarter 2013

Perotti, Enrico. 2012. The roots of shadow banking. www.voxeu.org 21 June 2012 2013. The Roots of Shadow Banking. CEPR Policy Insight No. 69, December 2013

Pozsar, Zoltan, T. Adrian, A. Ashcraft, and H. Boesky. 2010. "Shadow Banking." Staff Report No. 458. Federal Reserve Bank of New York.

Schmitz, Stefan W. 2012. The liquidity coverage ratio under siege. www.voxeu.org

Senior Supervisor Group. 2008. Observations on Risk Management Practices during the Recent Market Turbulence. March 62008. http://www.newyorkfed.org/newsevents/news/banking/2008/SSG_Risk_Mgt_doc_fi nal.pdf 
Sheng, Andrew. 2011. "Central Banking in an Era of Quantitative Easing." Working paper No. 684. Annandale-on-Hudson, NY: The Levy Economics Institute of Bard College.

Sidanius, Che and Filip Zikes. 2012. OTC derivatives reform and collateral demand impact. Financial Stability Paper No. 18 - October 2012

Simmons, Edward C. 1947. The Relative Liquidity of Money and Other Things. American Economic Review, Vol. 37, No. 2

Simons, Henry. 1936. "Rules versus Authorities in Monetary Policy." Journal of Political Economy 44 (1): 1-30.

Singh, Manmohan. 2012. Puts in the Shadow. IMF Working Paper WP/122/229 . 2013a.The Changing Collateral Space. IMF Working Paper WP/13/25

. 2013b. The Economics of Shadow Banking. In Heath, Alexandra, Matthew Lilley and Mark Manning. 2013. Liquidity and Funding Markets. Reserve Bank of Australia

Stein, Jeremy C. 2013a. Liquidity Regulation and Central Banking. At the "Finding the Right Balance" 2013 Credit Markets Symposium sponsored by the Federal Reserve Bank of Richmond, Charlotte, North Carolina, April 19, 2013

. 2013b. The Fire-Sales Problem and Securities Financing Transactions. At the Federal Reserve Bank of New York Workshop on Fire Sales as a Driver of Systemic Risk in Tri-party Repo and other Secured Funding Markets, New York, October 4, 2013

Smyth, Nick and Anne Wetherilt. 2011. Trading models and liquidity provision in OTC derivatives markets. Bank of England Quarterly Bulletin, Q4

Sunderam, Adi. 2012. Money Creation and the Shadow Banking System. Harvard Business School

Tarullo, Daniel K. 2013. Shadow Banking and Systemic Risk Regulation. Remarks at the American for Financial Reform and Economic Policy Institute conference, November 22

Tett, Gillian. 2013. Ideas adjust to new "facts" of finance. Financial Times. December 26

Thornton, Henry. 1802. An Inquiry into the Nature and Effects of the Paper Credit of Great Britain. London: George Allen and Unwin.

Turner, Adair. 2012. Monetary and Financial Stability: Lessons from the Crisis. Speech at South African Reserve Bank, 2 November 2012

2013. Too much debt, financial system stability and wider economic impacts. Speech at Chicago Federal Reserve Bank International Banking Conference, November 7 
Tucker, Paul. 2009. "The Repertoire of Official Sector Interventions in the Financial System: Last Resort Lending, Market-Making, and Capital.” Remarks at the Bank of Japan 2009 International Conference. Tokyo, Japan, May 27-28, 2009 2014. Regulatory Reform, Stability and Central Banking. Hutchins Center on Fiscal \& Monetary Policy. Brookings

U.S. Department of the Treasury. 2013. Treasury Borrowing Advisory Committee Discussion Charts by Calendar Year, Q2 2013: Availability of High-Quality Collateral.

Zorn, Lorie and A. García. 2011. "Central Bank Collateral Policy: Insights from Recent Experience.” Bank of Canada Review, Spring 